\title{
Perancangan Media Pembelajaran Mengenal Huruf Arab (Hijaiyah) untuk Anak Usia 4-6 Tahun dengan Menggunakan Software Pengolah Animasi 2 Dimensi
}

\author{
Titania Dwi Andini ${ }^{1}$, Achmad Bahar Wafa ${ }^{2}$ \\ ${ }^{1,2}$ Teknik Informatika, STMIK Asia Malang \\ titania@asia. ac.id
}

\begin{abstract}
ABSTRAK
Media Pembelajaran ini dinilai sangat bermanfaat karena membantu Anak pada Usia 4-6 tahun bisa lebih mudah menerima materi yang diajarakan selain itu juga membuat anak-anak tertarik untuk mempelajari materi yang disampaikan. Dalam media pembelajaran ini yang akan disampaikan adalah tentang Huruf Arab (Hijaiyah). Lebih ditujukan kepada anak pada usia 4-6 tahun, karena pada anak usia 4-6 tahun sangat mudah dan cepat untuk menghafal dari apa yang mereka lihat dan pelajari. Kecanggihan teknologi sekarang ini memudahkan siapapun mampu belajar membuat Media Pembelajaran seperti software pengolah animasi 2 dimensi, Macromedia Flash serta software pengolah gambar vektor, Corel Draw. Media pembelajaran ini memiliki konsep yang menarik, dari materi yang disampaikannya mudah dipahami, ditambah dengan gambar karakter maupun background yang unik akan membuat anak- anak tidak jenuh untuk mempelajarinya serta memahami isi dari materi yang disampaikan.
\end{abstract}

Kata Kunci : Media Pembelajaran; Huruf Arab (Hijaiyah); Anak Usia 4-6 Tahun; Animasi; 2 Dimensi.

ABSTRACT

This learning media is very useful because it helps Children at 4-6 years of age can more easily receive the material that is taught in addition to also make the children interested to learn the material delivered. In this learning media will be delivered is about the Arabic Letters (Hijaiyah). More aimed at children at 4-6 years old, because in children aged 4-6 years is very easy and quick to memorize from what they see and learn. The sophistication of technology now allows anyone to learn to make learning media such as 2-dimensional animation processing software, Macromedia Flash and vector image processing software, Corel Draw. This learning media has an interesting concept, from the material it conveys easily understood, coupled with unique character and background image will make the children unsaturated to learn it and understand the contents of the material presented.

Keywords : Learning Media; Arabic Letters (Hijaiyah); Children at 4-6 years; Animation; 2 Dimention

\section{PENDAHULUAN}

Menurut Undang-undang Sisdiknas tahun 2003, anak usia dini adalah anak yang berada pada rentan usia 0-6 tahun. Pada Masa ini merupakan masa emas atau golden age karena anak mengalami pertumbuhan dan perkembangan yang sangat pesat dan tidak tergantikan pada masa mendatang. Menurut penelitian dibidang neurologi yang diutarakan Slamet Suyanto (2005:6), menyatakan bahwa 50\% kecerdasan anak terbentuk dalam kurun waktu 4 tahun pertama. Setelah anak berusia 8 tahun perkembangan otaknya mencapai $80 \%$ dan pada usia 18 tahun mencapai 100\%. Pada usia 7 tahun anak telah memasuki jenjang sekolah formal yaitu Sekolah Dasar. Sehingga masa keemasan sebelum anak memasuki pendidikan formal adalah 4 tahun pertama hingga umur 6 tahun.

Perkembangan teknologi saat ini sangat mempengaruhi pola penyerapan informasi dan pola belajar anak usia dini. Penggunaan gadget maupun komputer sudah menjadi hal yang lumrah walaupun memang ada beberapa keluarga yang memproteksi anak mereka dalam mengenal atau membatasi penggunaannya dikarenakan alasan ekonomi, sosial atau alasan kesehatan penglihatan. Gadget maupun komputer sebagai media multimedia menyampaikan informasi yang dinamis, dimana pengguna bisa berinteraksi menghasilkan reaksi pada salah satu informasi berupa animasi. 
Animasi merupakan alat berkomunikasi yang disukai anak usia dini karena menampilkan gambar yang bergerak. Menurut Zeembry (20017:9) Animasi adalah rangkaian gambar yang disusun secara berurutan. Ketika rangkaian gambar tersebut ditampilkan dengan kecepatan yang memadai, rangkaian gambar tersebut akan terlihat bergerak. Kecepatan animasi biasanya diukur fps (frame per second), yaitu banyaknya gambar yang ditampilkan dalam satu detik. Animasi pertama kali dilakukan ditahun 1828 oleh Paul Roget dengan menciptakan thaumatrope. Jenis animasi yang paling banyak digunakan adalah animasi 2 Dimensi.

Pengenalan huruf hijaiyah (huruf arab) dilakukan pada anak sedini mungkin, karena bagi umat muslim, membaca Kitab Suci Al Qur'an akan mendapatkan pahala hingga akhir hayat, olehnya pengenalan huruf hijaiyah dapat dikenalkan pada masa keemasan perkembangan otak anak. Lalu timbul pertanyaan, "Bagaimana mereka (anak usia 4-6 tahun) dapat menerima materi huruf hijaiyah dengan senang hati?"

Perkembangan teknologi pada Kegiatan Belajar Mengajar (KBM) juga memiliki perkembangan pesat. Salah satunya menggunakan multimedia interaktif. Dijelaskan oleh Tway (1992) bahwa multimedia merupakan alat yang dapat menciptakan presentasi yang dinamis dan interaktif yang mengkombinasikan teks, grafik, animasi, audio dan gambar video. Multimedia terbagi menjadi dua kategori, yaitu: multimedia linier dan multimedia interaktif. Multimedia linier adalah suatu multimedia yang tidak dilengkapi dengan alat pengontrol apapun yang dapat dioperasikan oleh pengguna.

Diharapkan dengan menggunakan multimedia interaktif dapat menjawab pertanyaan saya di atas. Multimedia interaktif menjadi media informasi saat ini seperti yang diutarakan Criticos (1996) bahwa media merupakan salah satu komponen komunikasi, yaitu sebagai pembawa pesan dari komunikator menuju komunikan. Sedangkan pengertian dari informasi secara umum adalah data yang sudah diolah menjadi suatu bentuk lain yang lebih berguna yaitu pengetahuan atau keterangan yang ditujukan bagi penerima dalam pengambilan keputusan, baik masa sekarang atau yang akan datang (Gordon B. Davis, 1990:11)

Dalam mewujudkan keinginan saya, saya menggunakan software Adobe Flash CS3 dan software pengolah gambar vektor Corel Draw X6 sebagai aplikasi pendukung untuk menciptakan animasi 2 dimensi dengan multimedia interaktif untuk mengenalkan huruf hijaiyah pada anak usia 4-6 tahun. Diharapkan anak usia tersebut dapat mengenal huruf hijaiyah dengan senang karena dapat berinteraksi dengan aplikasi yang saya rancang dengan beberapa game.

\section{PEMBAHASAN}

Media pembelajaran ini dirancang untuk pengenalan huruf arab (Hijaiyah). Karena media pembelajaran ini untuk anak-anak tahun 4-6 tahun maka media pembelajaran ini menggunakan cerita atau bentuk lain dari huruf arab (hijiayah). Konsep ini dipilih karena memudahkan anak-anak pada usia 4-6 tahun untuk menghafal atau mengenal macammacam dari huruf hijaiyah itu.

Dengan pengambilan konsep cerita atau bentuk lain ini diharap dapat menyatu dengan tema media pembelajaran yaitu pengenalan huruf arab (Hijaiyah). Dan diharapkan lagi konsep ini mampu menarik minat anak- anak untuk belajar. Berikut rancangan menu (site map) aplikasi yang dirancang : 


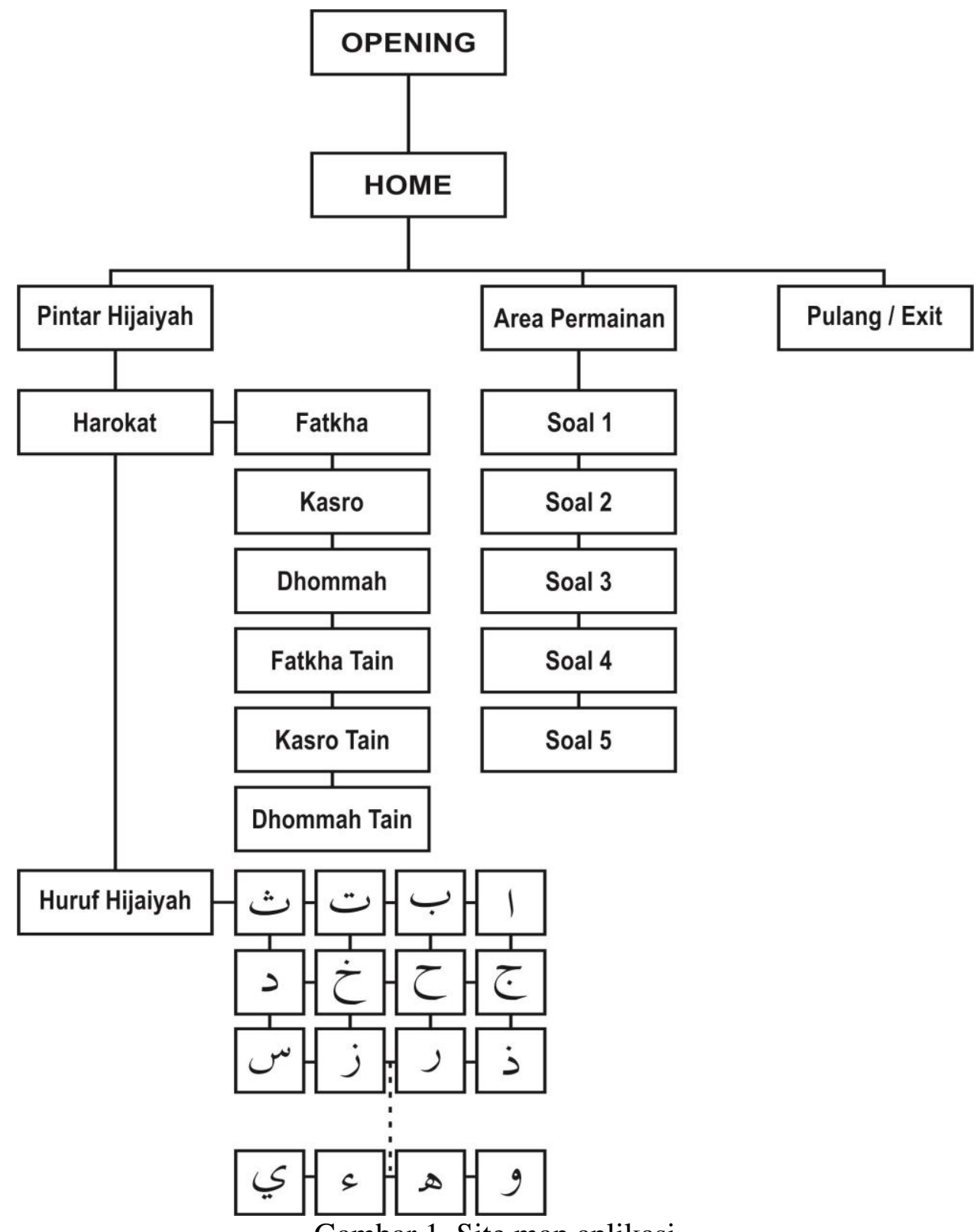

Gambar 1. Site map aplikasi

a. $\log 0$

Logo yang digunakan ini adalah sebuah tulisan yang bertulisan "Ngaji Yuk..." dengan didesain yang menarik dan menggunakan jenis tulisan (font) berkarakter anak-anak serta menggunakan warna yang solid

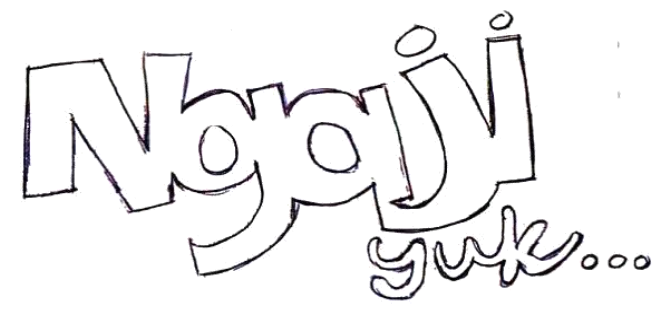

Gambar 2. Logo 
b. Karakter

Karakter yang akan diambil adalah karakter gambar anak kecil memakai baju busana muslim yang akan diperkenalkan dalam media pembelajaran tersebut. Karakter tersebut akan digambar ulang dan berbentuk dua dimensi.
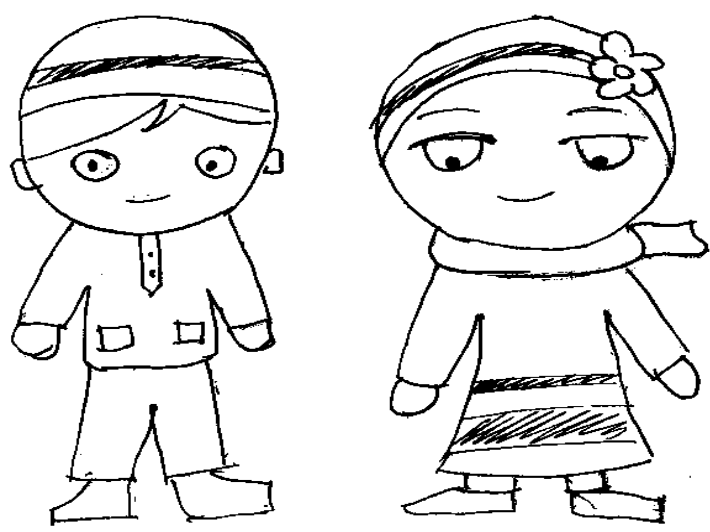

Gambar 3. Karakter

c. Background

Sama halnya dengan karakter, background akan digambar dan berbentuk dua dimensi

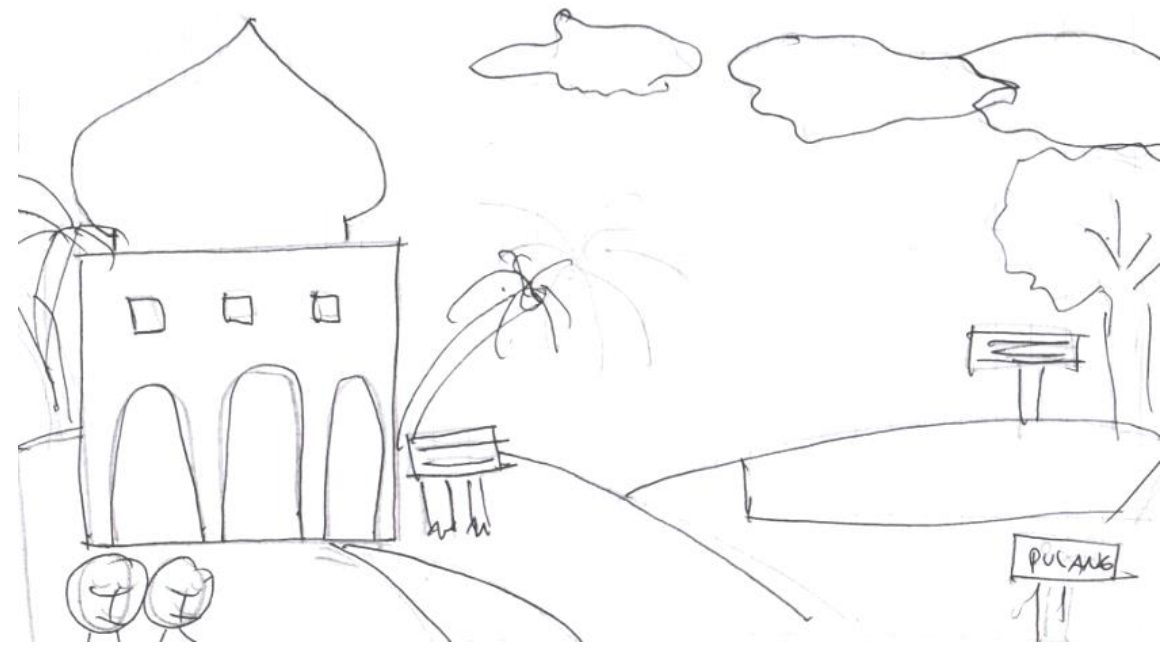

Gambar 4. Background

Dalam tahap direncanakan cerita dan alur media interaktif dengan gambar. Hal ini dimaksudkan sebagai acuan untuk proses pengerjaan media interaktif ini. Sehingga dalam proses pengerjaan nanti tidak terlalu melenceng dari encana semula dan storyboard memudahkan untuk mendahulukan yang lebih penting sehingga tidak akan ada waktu yang terbuang. Pada proses ini harus bisa membagi alur cerita yang sudah ada, supaya bisa di tuangkan dalam bentuk sketsa atau gambar pada lembar storyboard Dalam storyboard dijelaskan efek apa yang akan digunakan, durasi yang dibutuhkan dan suara yang akan digunakan. 


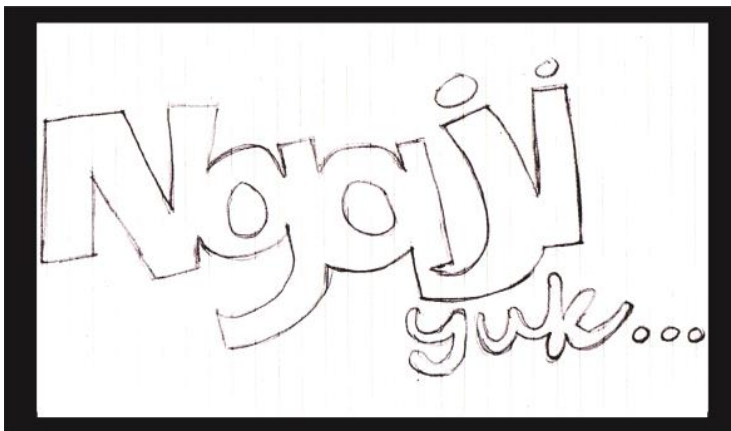

1. Pada scene awal (pembukaan) akan terdapat judul media pembelajaran. Kurang lebih 5 - 10 detik

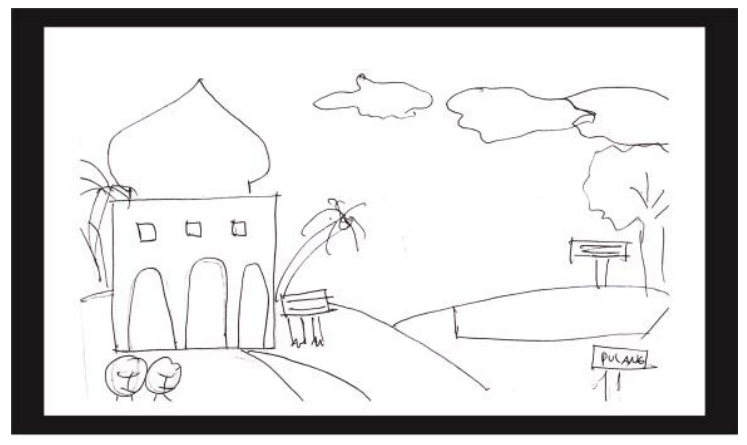

3. Pada scene inilah terdapat beberapa button yang bisa dipilih dan ada karakter seorang anak kecil terletak pada kiri bawah yang memberikan penjelasan tentang beberapa button.

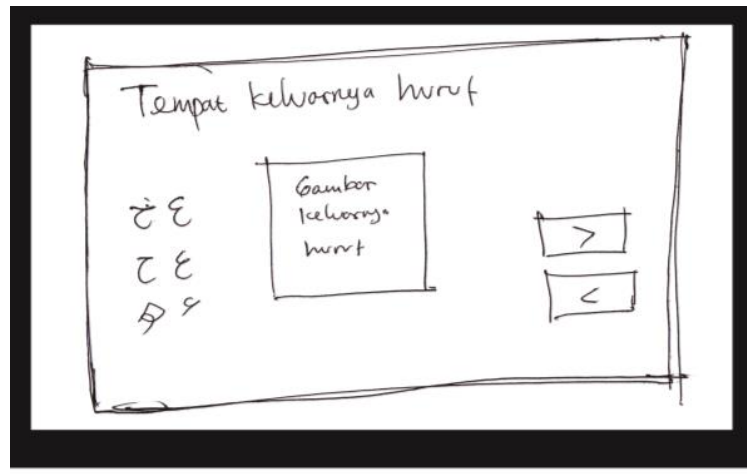

5. Pada scene inilah materi tentang Makhorijul Huruf (keluarnya Huruf Hijaiyah). Terdapat 2 button yang digunakan untuk menuju pada scene selanjutnya.

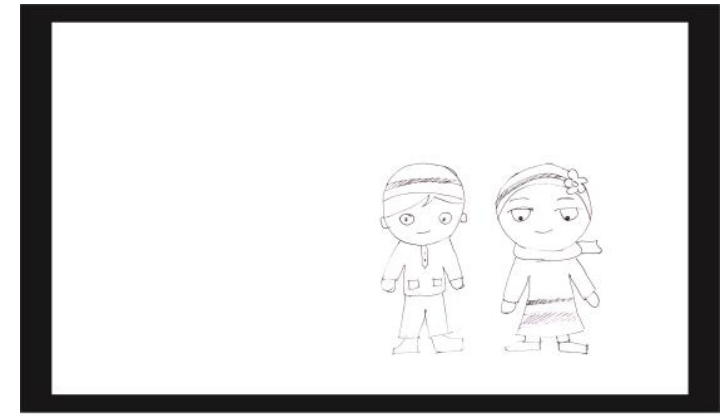

2. Pada scene ini terdapat karakter anak kecil dengan dubbing. Kurang lebih selama 10-25 detik

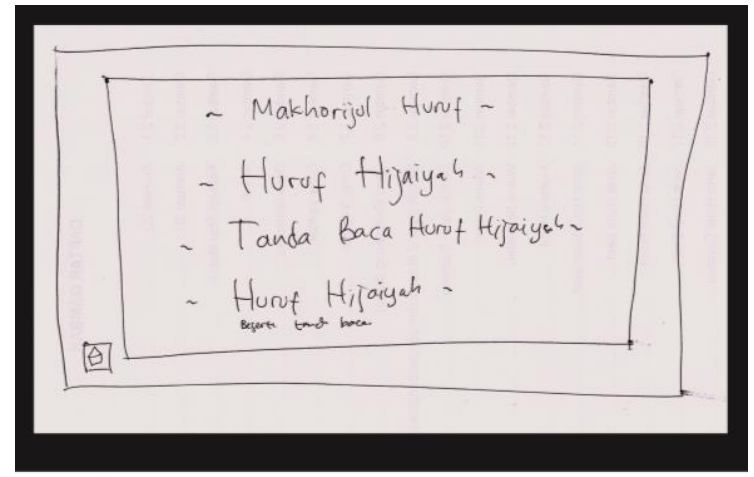

4. Pada scene terdapat 4 button yang digunakan untuk menuju materi yang diinginkan

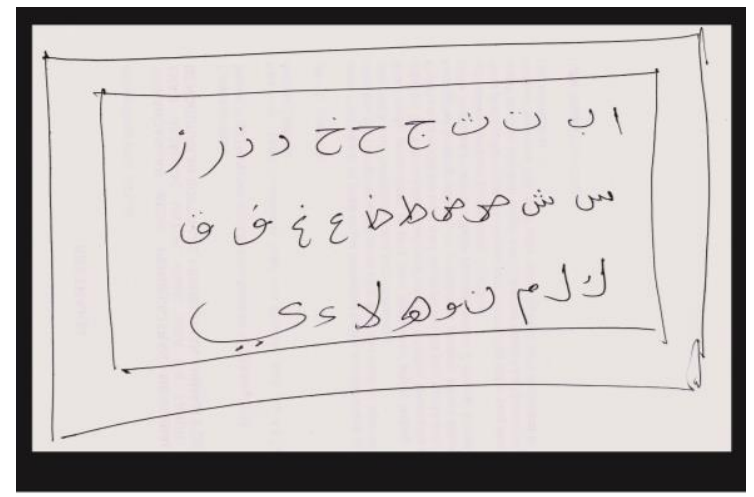

6. Pada scene ini tedapat beberapa pilihan Huruf Hijaiyah dari alif hingga ya'

\section{Gambar 5 Rancangan Storyboard}

Dalam tahapan Implementasi, berikut terpapar hasil pembuatan media pembelajaran menggunakan software pengolah animasi 2 dimensi:

a. Desain Layout

Dalam membuat sebuah media pembelajaran yang interaktif diperlukan banyak gambar. Gambar tersebut dikelompokan dalam layout. Untuk dapat menarik perhatian anak-anak dalam belajar diperlukan sebuah gambar yang menarik dan lucu. Berikut ini adalah tahapan dalam pembuatan desain layout.

\section{b. Desain Karakter}

Karakter yang akan diambil adalah karakter gambar anak kecil memakai baju busana 
muslim yang akan diperkenalkan dalam media pembelajaran tersebut. Karakter tersebut akan digambar ulang dan berbentuk dua dimensi. Sehingga karakter tersebut akan berbentuk seperti gambar vector.

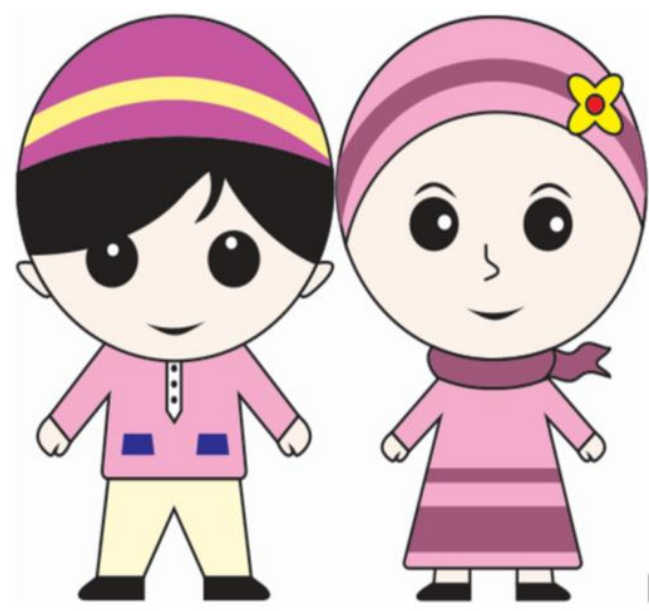

Gambar 6. Implementasi Karakter

c. Desain Background

Desain background menggunakan tampilan dari depan masjid dengan background sebuah gunung.

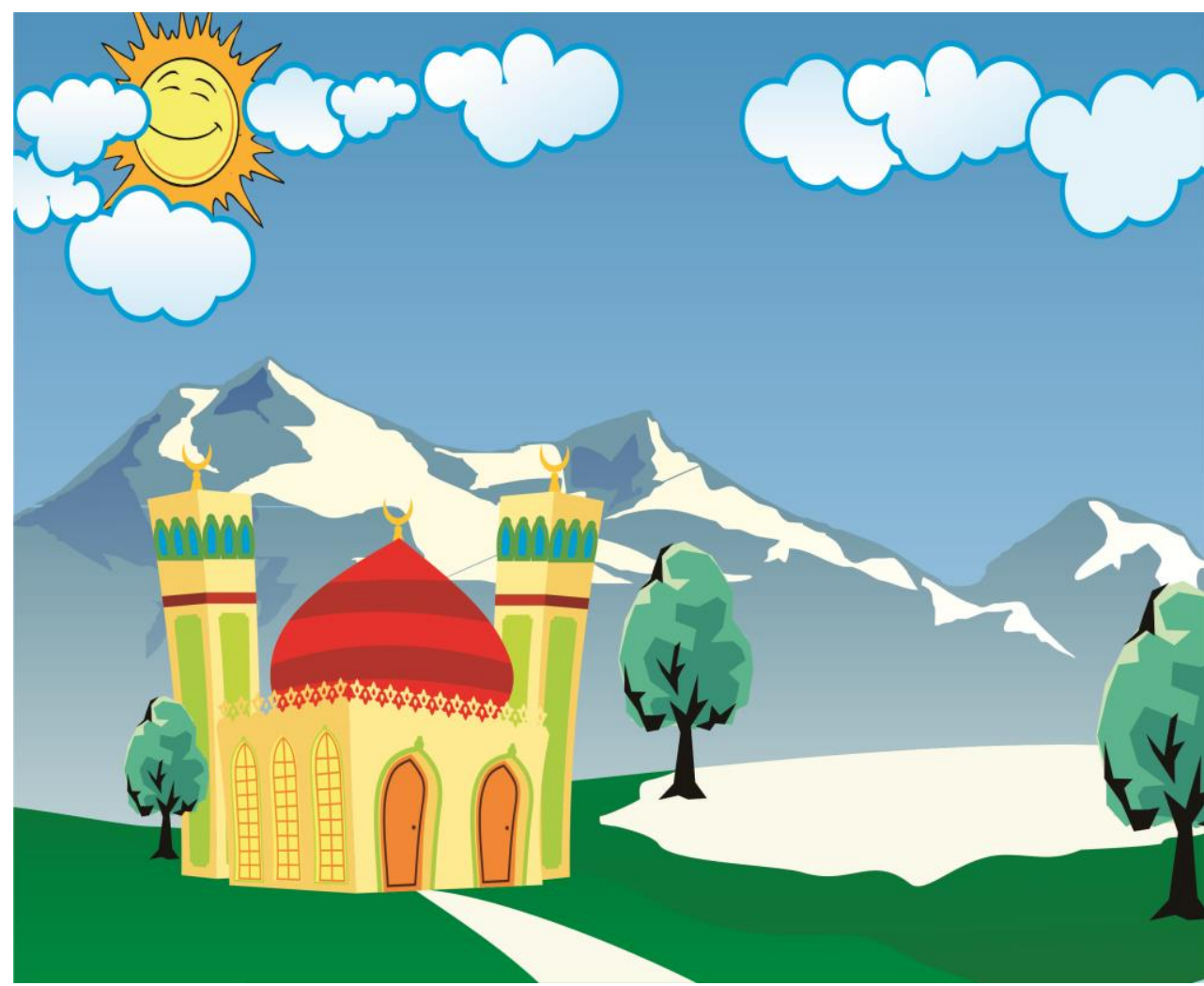

Gambar 7. Implementasi Background

d. Desain Menu

Dalam media pembelajaran ini terdapat tombol-tombol menu untuk mengoperasikannya. Didalam menu terdapat beberapa menu pilihan yang dapat dipilih 
sesuai dengan keinginan tanpa harus melewati tahapan tertentu. Pada main menu atau menu utama terdapat tiga tombol muncul pilihan, yaitu: Pintar Hijaiyah, Area Permainan, Pulang.

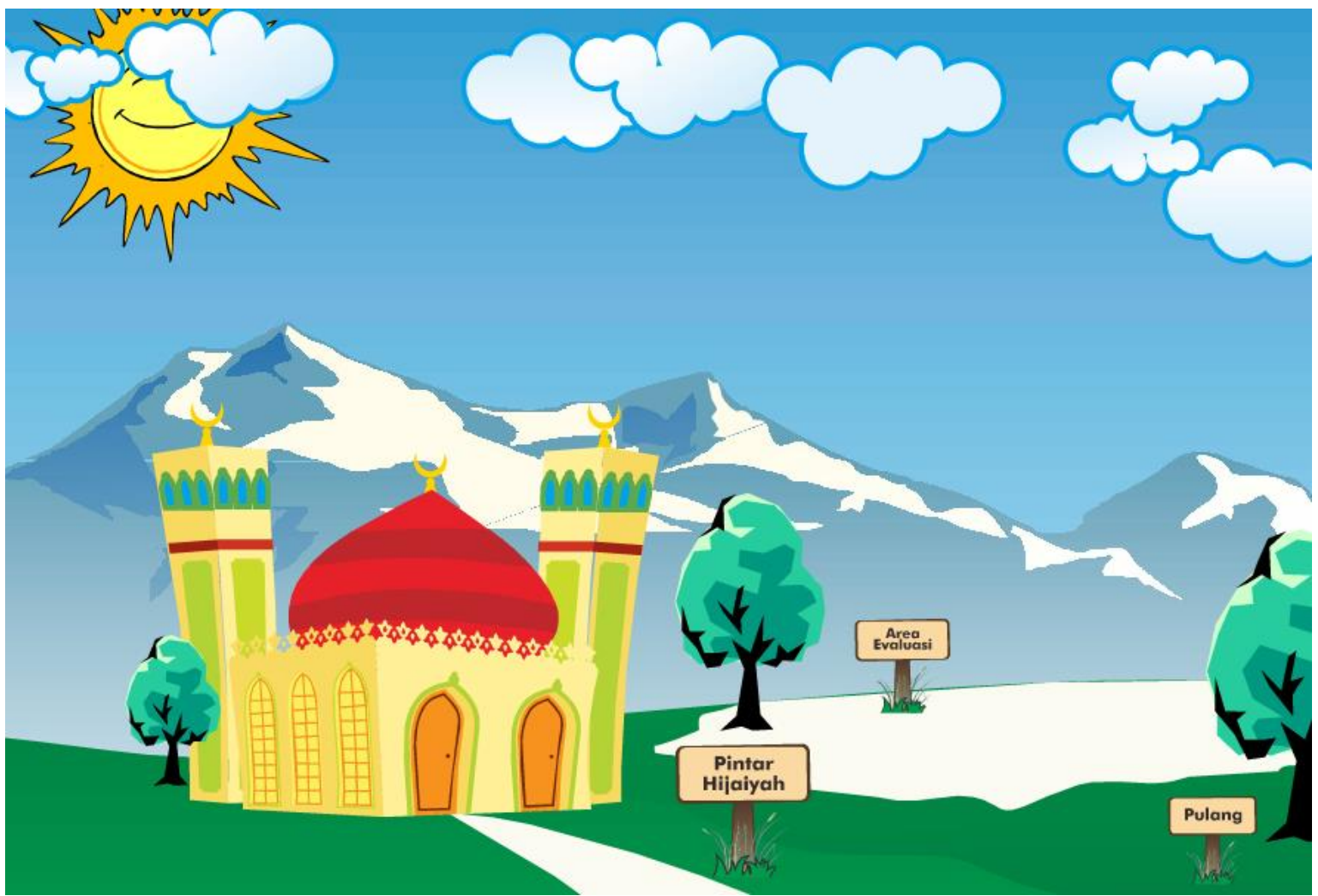

Gambar 8 Implementasi Menu Utama

Terdapat Action Script pada tombol tersebut. Berikut adalah Action Script yang terdapat pada tombol Pintar hijaiyah:

on (release) \{

loadMovieNum("ngaji. swf", 1);

\}

Selanjutnya masuk pada tampilan Pintar Hijaiyah terdapat beberapa pilihan. Berikut adalah gambar tampilan Pintar Hijaiyah

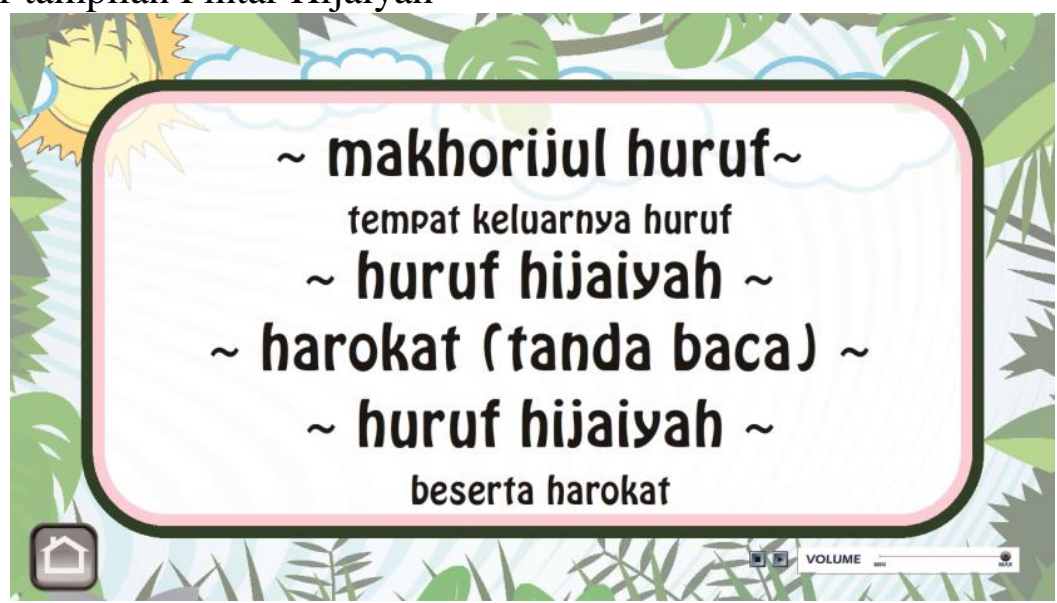


Gambar 9. Tampilan Pintar Hijaiyah

Terdapat 4 button yaitu: makhorijul huruf, huruf hijaiyah, harokat (tanda baca), dan huruf hijaiyah beserta harokat. Berikut adalah gambar tampilan makhorijul huruf

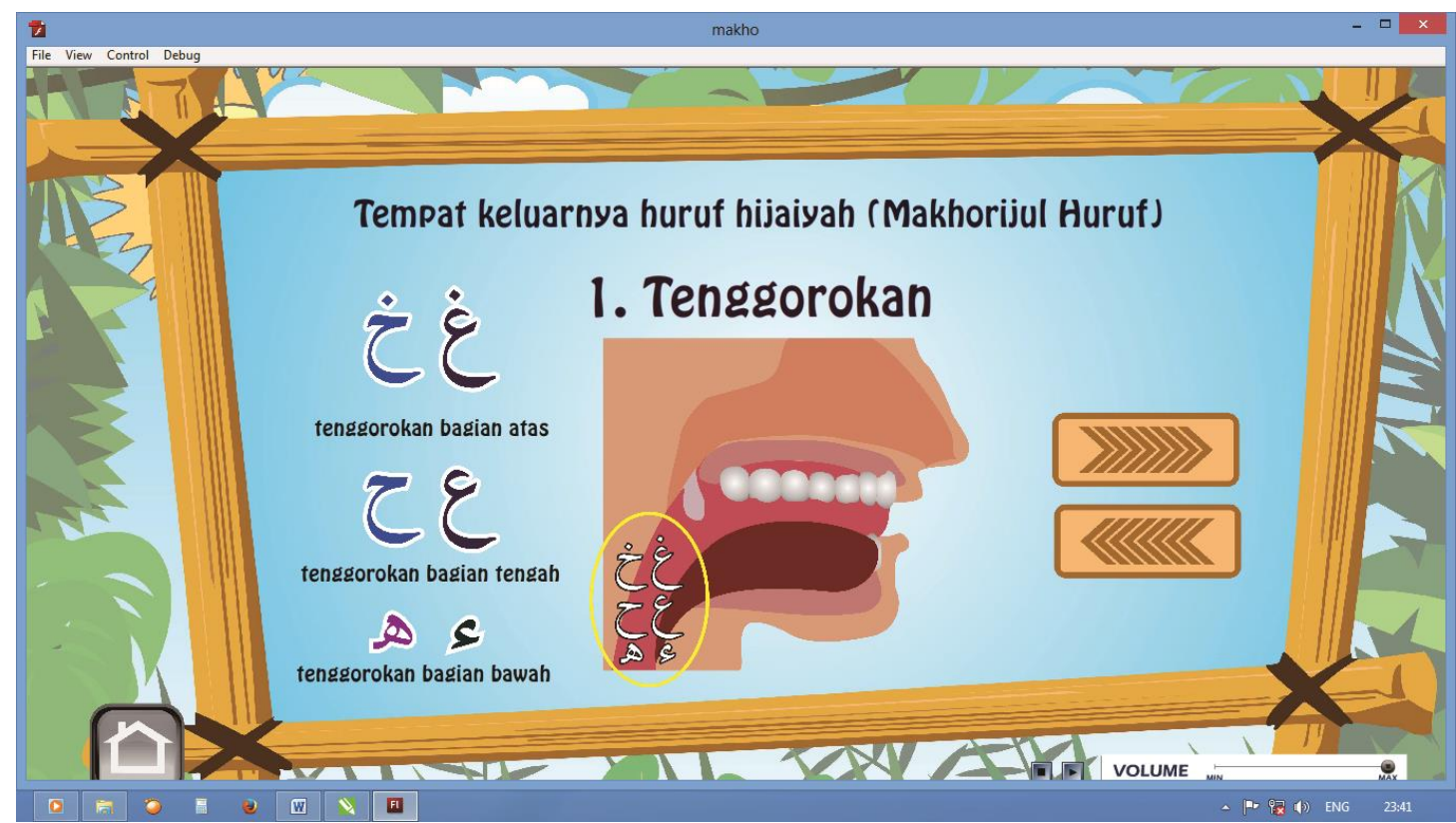

Gambar 10. Tampilan Makhorijul huruf

Pada scene Makhorijul Huruf terdapat keterangan tentang keluarnya huruf hijaiyah. Berisi 3 button. Button Back, Button Forward, dan Button Home. Berikut adalah Action Script yang terdapat pada tombol Forward:

on (release) \{ gotoAndPlay("Scene 2", 1); \}

Action Script pada tombol Back:

on (release) \{ gotoAndPlay("Scene 1", 1); \}

Berikut adalah gambar huruf hijaiyah

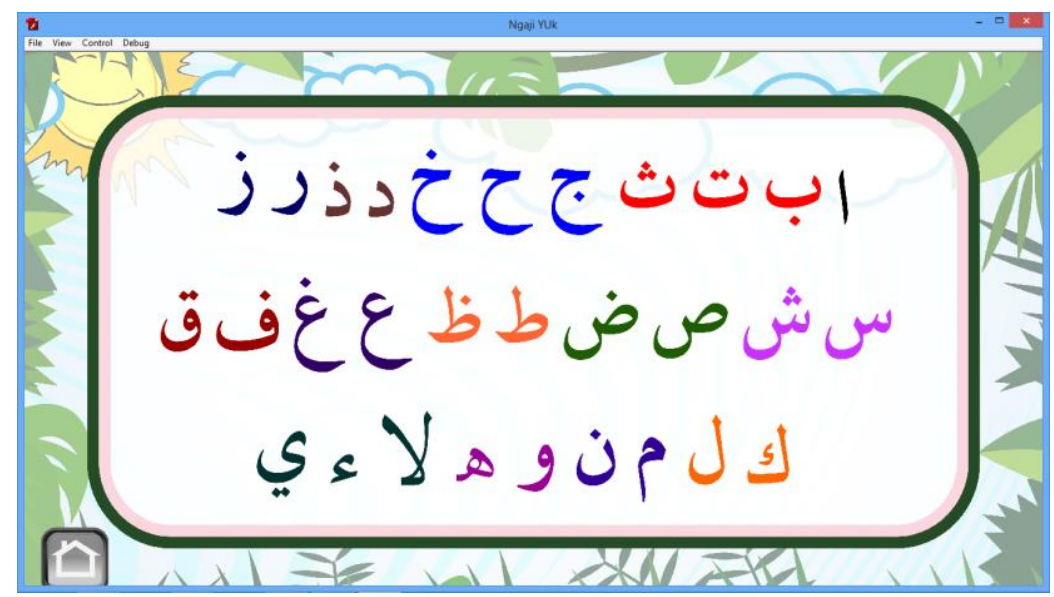

Gambar 11. Tampilan Pintar Hijaiah 
Pada tampilan Pintar Hijaiyah terdapat tombol huruf hijaiyah dari Alif sampai Ya'. Bila dipilih salah satu huruf hijaiyah maka nantinya akan masuk ke tampilan berikutnya. Berikut adalah Action Script yang terdapat pada tombol alif :

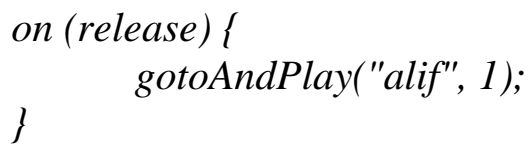

Selanjutnya masuk pada tampilan Huruf Hijaiyah Alif . Berikut adalah gambar alif:

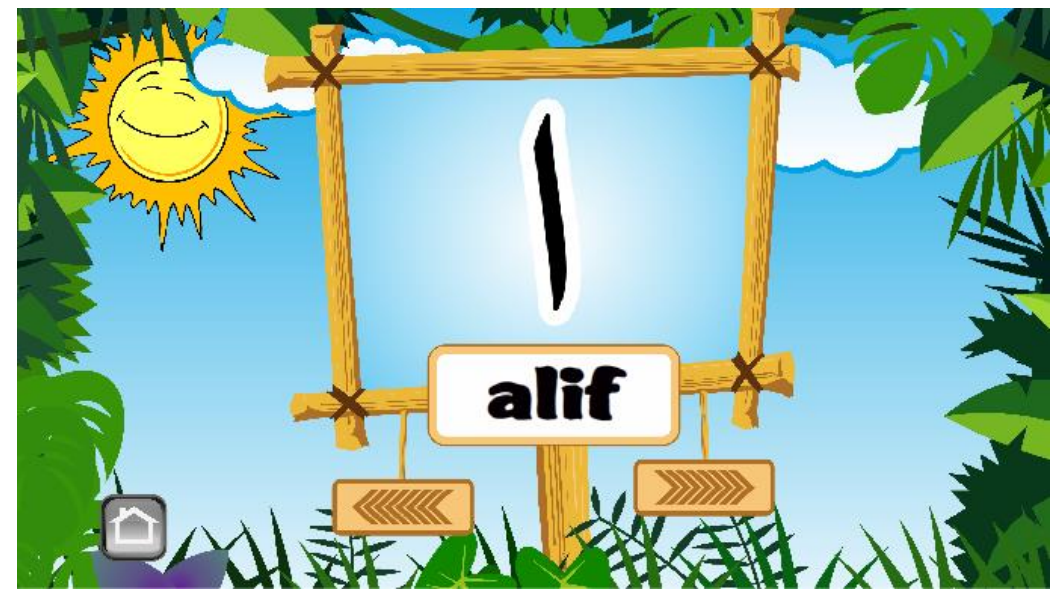

Gambar 12. Alif

Dalam tampilan ini terdapat button next yang berada di bawah huruf hijaiyah yang berfungsi untuk melanjutkan ke huruf hijaiyah selanjutnya, button previous yang berada di bawah huruf hijiayah yang berfungsi untuk kembali ke huruf hijaiyah sebelumnya, button kembali berfungis untuk kembali ke tampilan awal. Berikut adalah Action Script yang terdapat pada tombol next :

\section{on (release) \{ gotoAndPlay(31); \}}

Setelah sampai pada frame yang terkahir. Diberi script yang melanjutkan kepada scene selanjutnya.

$$
\text { gotoAndPlay("ba", 1); }
$$

Berikut adalah Action Script yang terdapat pada tombol previous :

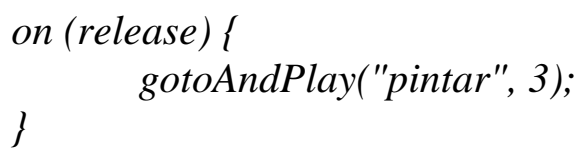

Berikut adalah Action Script yang terdapat pada tombol kembali :

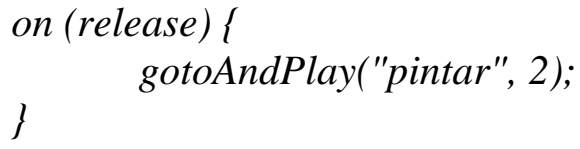


Pada tampilan Harokat (tanda baca) terdapat tombol harokat Bila dipilih salah satu Harokat maka nantinya akan masuk ke tampilan berikutnya. Adapun gambar harokat (tanda baca) sebagai berikut

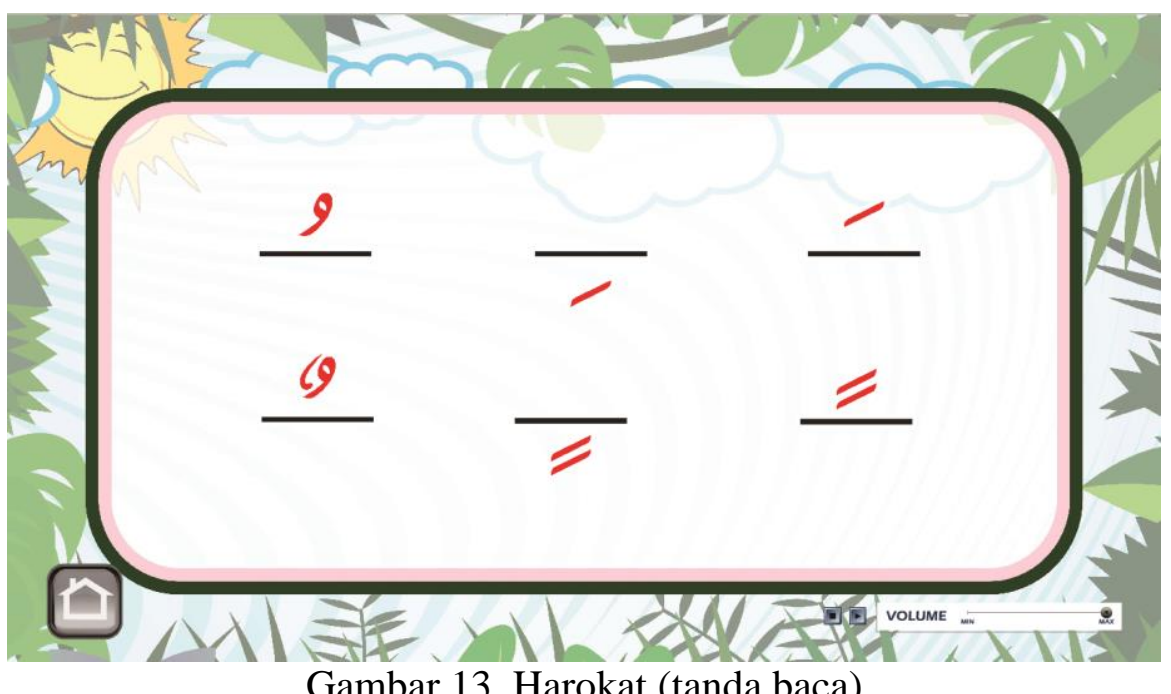

Berikut adalah Action Script yang terdapat pada tombol Alif :

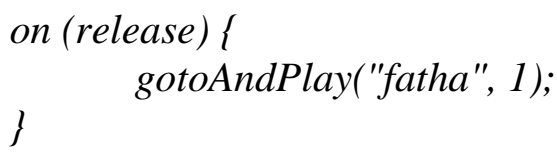

Selanjutnya masuk pada tampilan Harokat Fatha. Adapun gambar harokat Fatha sebagai berikut

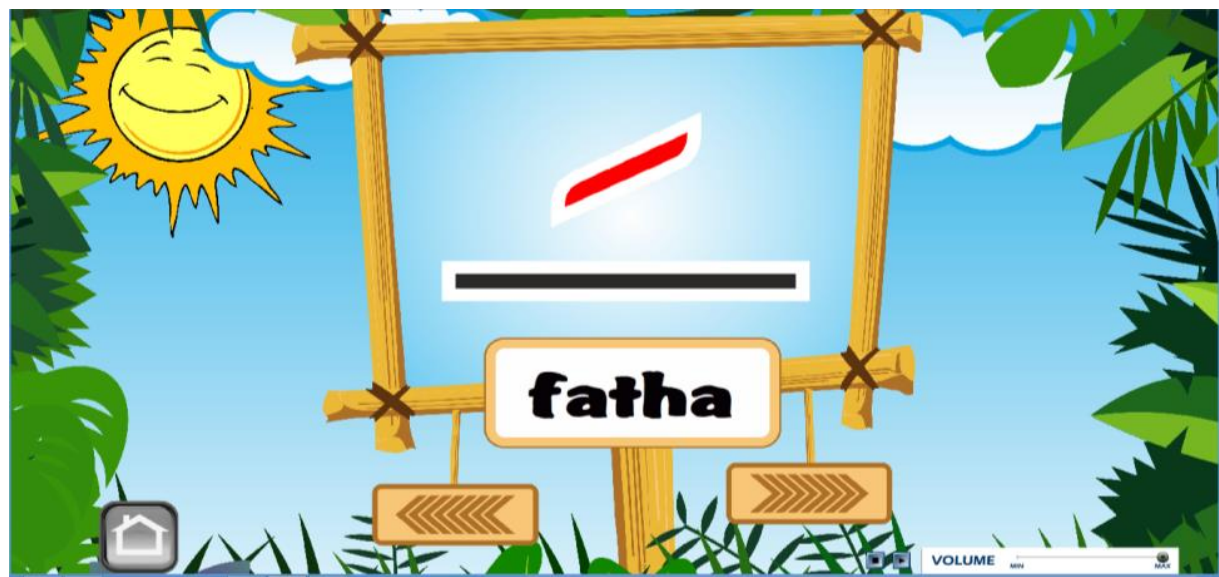

Gambar 14. Harokat Fatha

Isi dari tombol Huruf Hijaiyah (beserta harokat) ini terdapat beberapa huruf hijaiyah dari Alif sampai Ya yang materinya adalah materi yang ada di dalam tombol pintar hijiayah. Adapun gambar huruf hijaiyah (beserta harokat) sebagai berikut 


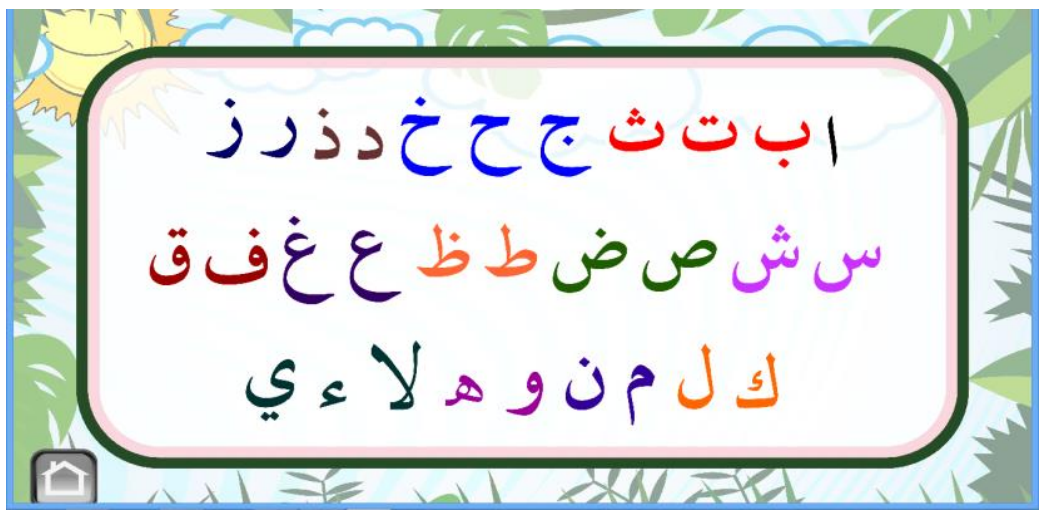

Gambar 15. Huruf Hijaiyah (beserta harokat)

Jika dipilih salah satu maka akan menuju ke tampilan selanjutnya yaitu berisi tentang huruf hijaiyah yang berharokat. Berikut adalah gambar huruf hijaiyah (beserta harokat)

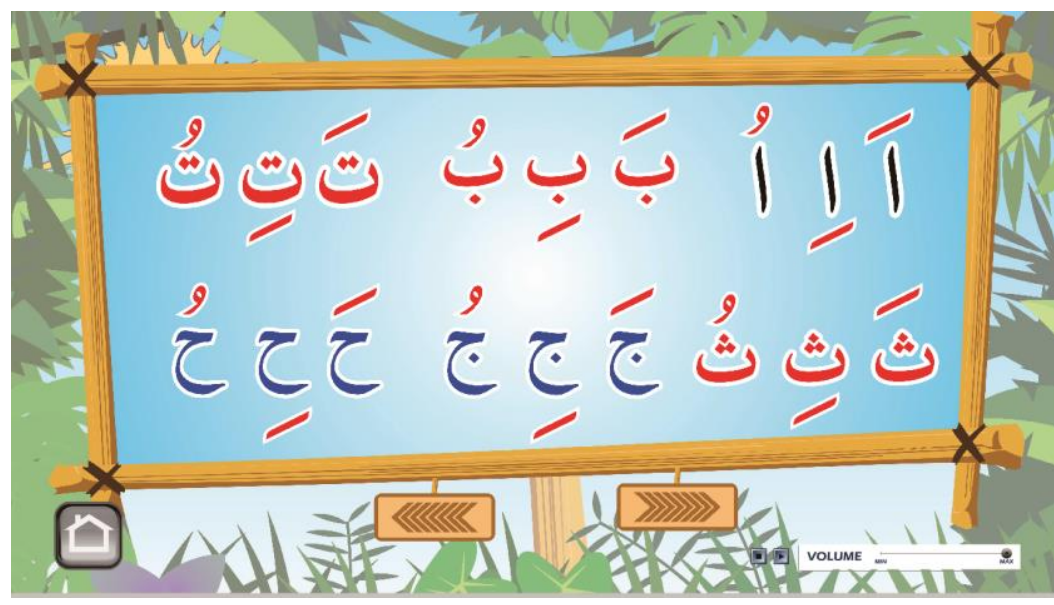

Gambar 16. Huruf Hijaiyah (beserta harokat)

Berikut action Script jika dipilih salah satu dari huruf hijiyah.

on (release) \{ gotoAndPlay("1", 1); \}

Isi dari tombol area kuis ini terdapat beberapa soal yang materinya adalah materi yang ada di dalam tombol pintar hijiayah. Berikut adalah Action Script yang terdapat pada tombol Area kuis.

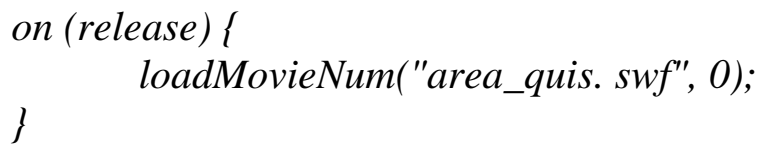

Berikut ini adalah tampilan dari menu Area Kuis. 


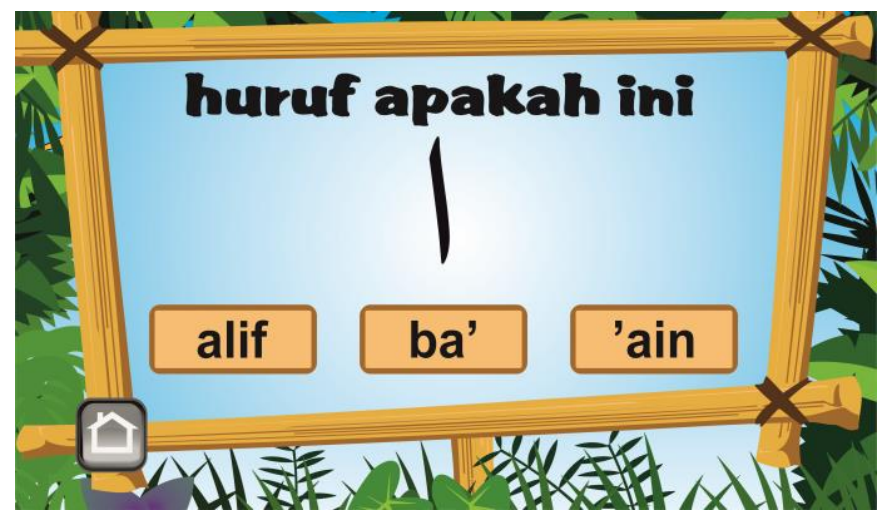

Gambar 17. isi kuis

Tombol ini berfungsi untuk mengakhiri atau menutup program .

\section{KESIMPULAN}

Dari perancangan dan implementasi media pembelajaran pengenalan huruf Hijayah di atas, pemilihan warna, pemilihan jenis tulisan dan konten telah disesuaikan dengan pendekatan pada anak usia dini. Pendekatan menggunakan media kuis juga dapat diterapkan pada media pembelajaran sehingga anak usia dini dapat terpancing untuk mengenal lebih lanjut huruf hijaiyah beserta tanda bacanya.

Diharapkan media pembelajaran yang berkembang di masa sekarang dapat memaksimalkan kemampuan multimedia sehingga dapat mendukung animasi 2 dimensi maupun animasi 3 dimensi sehingga diharapkan dapat memotivasi pengguna untuk mengenal dan memahami topik maupun isi yang disampaikan.

\section{DAFTAR PUSTAKA}

Criticos. 2016. International Encyclopedia of Educational Technology 2nd edition. New York: Elsevior Scienc.

Danton. 2001. Tipografi Dalam Desain Grafis. Jakarta: Gramedia Pustaka Utama

Gordon B Davis. 2006. Management Information System Conceptual Fondation Structure and Developer.

Hasbullah. 2005. Dasar Ilmu Pendidikan. Jakarta: PT Raja Grasindo Persada

Istanto. 1999. Peran Televisi dalam Masyarakat Citraan Dewasa Ini - Sejarah, Perkembangan dan Pengaruhnya. Jakarta.

Kusrianto, Adi. 2006. Pengantar Desain Komunikasi Visual. Yogyakarta: Andi Offset.

Peter Burke, Briggs. 2006. Sejarah Sosial Media dari Gutenberg sampai internet. Yayasan Obor Indonesia.

Sanyoto, Ebdi Sadjiman. 2005. Nirmana: Dasar-dasar Seni dan Desain. Jakarta: Jalasutra Sipahelut, Atisah. 1991. Dasar-dasar Desain. Jakarta: Debdiknas.

Sujiono, Yuliani Nurani. 2008. Konsep Dasar Pendidikan Anak Usia Dini.

Suyanto, Slamet. 2005. Dasar-dasar pendidikan anak usia dini. Yogyakarta: Hikayat Publishing.

Tway, Linda E. 1992. Welcome to Multimedia. New York: MIS Press.

Wong. 1995. Beberapa Asas Merancang Dwimatra. Bandung: ITB.

Zeembry \& Bunadi, Suriman. 2007. Membuat animasi kartu ucapan dengan Flash 8. Jakarta. PT: Elex Media Komputindo. 